\title{
Preventing smoking during pregnancy: the importance of maternal knowledge of the health hazards and of the treatment options available*
}

\author{
Prevenção do tabagismo na gravidez: importância do conhecimento materno \\ sobre os malefícios para a saúde e opções de tratamento disponíveis \\ André Luís Bertani, Thais Garcia, Suzana Erico Tanni, Irma Godoy
}

\begin{abstract}
Objective: To examine the pattern of tobacco use and knowledge about tobacco-related diseases, as well as to identify popular types of electronic media, in pregnant women, in order to improve strategies for the prevention or cessation of smoking among such women. Methods: A cross-sectional study involving 61 pregnant women, seen at primary care clinics and at a university hospital, in the city of Botucatu, Brazil. For all subjects, we applied the Hospital Anxiety and Depression Scale. For subjects with a history of smoking, we also applied the Fagerström Test for Nicotine Dependence, and we evaluated the level of motivation to quit smoking among the current smokers. Results: Of the 61 pregnant women evaluated, $25(40.9 \%)$ were smokers (mean age, $26.4 \pm$ 7.4 years), $24(39.3 \%)$ were former smokers (26.4 \pm 8.3 years), and $12(19.8 \%)$ were never-smokers $(25.1 \pm 7.2$ years). Thirty-nine women (63.9\%) reported exposure to passive smoking. Of the 49 smokers/former smokers, 13 $(26.5 \%)$ were aware of the pulmonary consequences of smoking; only $2(4.1 \%)$ were aware of the cardiovascular risks; $23(46.9 \%)$ believed that smoking does not harm the fetus or newborn infant; 21 (42.9\%) drank alcohol during pregnancy; $18(36.7 \%)$ reported increased cigarette consumption when drinking; $25(51.0 \%)$ had smoked flavored cigarettes; and $12(24.5 \%)$ had smoked a narghile. Among the 61 pregnant women evaluated, television was the most widely available and favorite form of electronic media (in 85.2\%), as well as being the form most preferred (by 49.2\%). Conclusions: Among pregnant women, active smoking, passive smoking, and alternative forms of tobacco consumption appear to be highly prevalent, and such women seem to possess little knowledge about the consequences of tobacco use. Educational programs that include information about the consequences of all forms of tobacco use, employing new and effective formats tailored to this particular population, should be developed, in order to promote smoking prevention and cessation among pregnant women. Further samples to explore regional and cultural adaptations should be evaluated.
\end{abstract}

Keywords: Pregnancy; Health knowledge, attitudes, practice; Smoking; Mass media; Smoking cessation; Primary prevention.

\section{Resumo}

Objetivo: Examinar o padrão de consumo do tabaco e conhecimentos sobre as doenças relacionadas ao tabaco, assim como identificar os tipos mais populares de mídias entre gestantes para aprimorar estratégias para a prevenção e a cessação do tabagismo entre essas mulheres. Métodos: Estudo transversal com 61 gestantes atendidas em um hospital universitário e em unidades básicas de saúde em Botucatu, SP. A Escala Hospitalar de Ansiedade e Depressão foi aplicada a todas as participantes. Para aquelas com história de tabagismo, também foi aplicado o Teste de Fagerström para Dependência de Nicotina, e foi avaliado o grau de motivação para cessação tabágica nas fumantes. Resultados: Das 61 gestantes avaliadas, 25 (40,9\%) eram fumantes (média de idade, 26,4 \pm 7,4 anos), 24 (39,3\%) eram ex-fumantes (média de idade, 26,4 $\pm 8,3$ anos), e 12 (19,8\%) nunca fumaram (média de idade, 25,1 \pm 7,2 anos). A exposição passiva foi relatada por 39 gestantes (63,9\%). Das 49 fumantes/ex-fumantes, $13(29,6 \%)$ conheciam as consequências pulmonares do tabagismo; somente $2(4,9 \%)$ conheciam os riscos cardiovasculares; $23(46,9 \%)$ acreditavam que fumar não causa nenhum problema para o feto ou o recém-nascido; $21(42,9 \%)$ consumiram álcool durante a gestação; $18(36,7 \%)$ relataram aumento no consumo de cigarros quando bebiam; $25(51,0 \%)$ experimentaram cigarros com sabores; e $12(24,5 \%)$ fumaram narguilé. Entre as 61 gestantes avaliadas, a televisão foi o tipo de mídia mais disponível e favorita $(85,2 \%)$, assim como a mais preferida $(49,2 \%)$. Conclusões: Entre gestantes, o fumo ativo, o fumo passivo e o uso de formas alternativas de consumo de tabaco parecem ser altamente prevalentes, e tais mulheres parecem possuir poucos conhecimentos sobre as consequências do uso de tabaco. Programas educacionais que incluam informações sobre as consequências de todas as formas de uso de tabaco, utilizando formatos novos e efetivos para esta população específica, devem ser desenvolvidos para promover a prevenção/cessação do tabagismo entre gestantes. Amostras adicionais para explorar diferenças culturais e regionais são necessárias.

Descritores: Gravidez; Conhecimentos, atitudes e prática em saúde; Hábito de fumar; Meios de comunicação de massa; Abandono do hábito de fumar; Prevenção primária.

*Study carried out in the Pulmonology Division of the Department of Internal Medicine, Botucatu School of Medicine, São Paulo State University, Botucatu, Brazil.'

Correspondence to: André Luís Bertani. Faculdade de Medicina de Botucatu, Unesp, Distrito de Rubião Junior, s/n, CEP: 18618970, Botucatu, SP, Brasil. Tel/Fax: 5514 3880-1171. E-mail: andrelubert@gmail.com

Financial support: None.

1 [sic] Botucatu Medical School, Unesp - Universidade Estadual Paulista, Botucatu Campus, Department of Internal Medicine, Pulmonology Division, Botucatu, Brazil.

Submitted: 4 November 2014. Accepted, after review: 27 January 2015. 


\section{Introduction}

Although the prevalence of smoking in the general population is well known, few studies have addressed smoking in pregnant women. In the United States, the prevalence of maternal smoking during pregnancy is estimated to be 25\%. ${ }^{(1)}$ A study evaluating pregnant women seen at primary care units in the state of São Paulo, Brazil, showed that $19.2 \%$ actively smoked (during pregnancy and breastfeeding); $28.2 \%$ were active and passive smokers; and $16.8 \%$ were exposed to passive smoking only. ${ }^{(2)}$ In 2011, another study, conducted in the Brazilian state of Rio Grande do Sul, evaluated anthropometric measurements of neonates born to 2,484 women and showed that, during pregnancy, 23.3\% of those women had smoked and $28.9 \%$ had been continuously exposed to secondhand smoke. ${ }^{(3)}$

Anti-smoking policies in Brazil are quite advanced. The tobacco industry is required to label packages with warnings about the health consequences of smoking, and there are laws prohibiting smoking in collective and indoor environments. Direct and indirect merchandising and sponsorship by the tobacco industry are also prohibited. ${ }^{(4-6)}$ However, the industry continues to employ strategies such as adding flavors to conventional cigarettes to change the taste and smell, in order to recruit new smokers from among women and adolescents. It should be borne in mind that flavored cigarettes and alternative forms of tobacco deliver all of the chemicals found in conventional cigarettes, ${ }^{(7)}$ and the prevalence of the use of such products remains unknown.

The study and analysis of pregnant women and smoking, as well as of the characteristics of nicotine addiction and its adverse health consequences, are fundamental to developing tools for the prevention and treatment of smoking in this population. There have been few studies evaluating knowledge of the hazards of smoking among pregnant women in Brazil, ${ }^{(2,3,8)}$ and none have evaluated technology preferences with the objective of designing interventions targeting such women. Therefore, the main objective of the present study was to examine the pattern of tobacco use and knowledge about tobacco-related diseases, as well as to identify the preferred forms of electronic media, in pregnant women, in order to improve strategies for promoting smoking prevention and cessation among such women.

\section{Methods}

\section{Subjects}

Between January and July of 2012, we recruited 61 pregnant women from among those attending routine appointments at the public prenatal care clinic of a university hospital and at primary care clinics in the city of Botucatu, Brazil. The study was approved by the Research Ethics Committee of the São Paulo State University Botucatu School of Medicine, also in the city of Botucatu. All participants (or their parents or legal guardians) gave written informed consent.

\section{Study design and procedures}

This was a descriptive cross-sectional study. The only exclusion criterion was refusal to participate. An investigator approached each pregnant woman while she was waiting to be seen and explained the aims of the study. The investigator was not a member of the health care team responsible for the treatment of the women recruited and visited the site only to conduct the interviews. All of the women invited agreed to participate and were directed to a room to be interviewed, in order to complete the study questionnaires. The interviews were conducted face-to-face, the investigator using a questionnaire developed specifically for the present study. The pregnant women freely answered questions about active and passive smoking, smoking habits during social activities, consumption of alcohol, use of alternative forms of smoking, and knowledge about the health hazards of smoking in general, as well as about the adverse health consequences of smoking during pregnancy, not only for the mother but also for the fetus and the newborn infant. In addition, all of the women completed the Hospital Anxiety and Depression Scale (HADS) ${ }^{(9)}$; those who were smokers or former smokers took the Fagerström Test for Nicotine Dependence ${ }^{(10)}$; and we assessed the motivational stage of change (level of readiness to quit smoking) using the model devised by DiClemente \& Prochaska. ${ }^{(11)}$ All personal information was kept confidential.

\section{Statistical analyses}

We used the chi-square test to compare the proportions and ANOVA with Tukey's test to compare means. Both evaluations were performed with a power of $80 \%$ and a level of significance of $5 \%$. 


\section{Results}

Of the 61 pregnant women evaluated, 25 $(40.9 \%)$ were smokers (mean age, $26.4 \pm 7.4$ years), 24 (39.3\%) were former smokers (26.4 \pm 8.3 years), and $12(19.8 \%)$ were never-smokers $(25.1 \pm 7.2$ years). The main characteristics of those three groups are presented in Table 1 . Most of the women were married and were smokers or former smokers. Only 7 women (11.5\%) were over 36 years of age. The predominant level of education was $\leq 9$ years of schooling. Most of the women interviewed reported having been exposed to passive smoking, the prevalence of such exposure being highest among the smokers and never-smokers. Of the 25 smokers, 12 (49.2\%) reported that their husband smoked, and 4 (14.7\%) reported that at least one member of the household smoked. Abortion due to fetal malformation was reported only by women who were smokers or former smokers. Of the 18 women (29.7\%) who had husbands who did not smoke, 10 (54.5\%) were former smokers.

Among the 49 pregnant women who were smokers or former smokers, the age at smoking initiation ranged from 9 years to 25 years. Of the 8 women (16.3\%) who had started smoking by 12 years of age, 7 (87.5\%) were current smokers ( $p=0.023)$. In contrast, we found no association between the age at smoking initiation and current smoking among the women who had started smoking after 12 years of age. The proportional distribution of the use of alternative forms of tobacco consumption-flavored cigarettes, clove cigarettes, water pipe (narghile), and electronic cigarettes-by the smokers and former smokers is presented in Table 2.

The proportion of women reporting wheezing was higher among the smokers than among the former smokers and never-smokers (87.5\% vs. $12.5 \%$ and $0 \%$, respectively; $p=0.030$ ). In addition, a history of hypertension was observed only among the smokers and former smokers, of whom 14 (55.5\%) and 11 (44.5\%), respectively, reported having received such a diagnosis. Among women whose HADS scores were suggestive of anxiety or depression (Table 3 ), the majority were smokers. Five (18.4\%) of the 25 smokers reported that they continued to smoke because of anxiety, whereas $3(12.2 \%)$ reported smoking for pleasure.

Our findings related to how much knowledge pregnant women possess about the adverse health consequences of smoking were disappointing (Table 4). Most of the pregnant smokers and former smokers were unaware of the hazards that smoking poses to fetuses and newborn infants, as well as of tobacco-related diseases in general.

Regarding the motivational stage of change, we found that the proportion of smokers in the pre-contemplative stage was higher than was that of those in the contemplative stage (68\% vs. $32 \% ; p=0.024)$. According to the results of the Fagerström Test for Nicotine Dependence, $15(60 \%)$ of the smokers and 14 (58.3\%) of the former smokers had a low degree of nicotine dependence. However, 12 (49\%) of the smokers cited nicotine dependence as the main motivator for their continued smoking. We identified a reduction in smoking during pregnancy, in comparison with smoking before pregnancy (Figure 1). Of the 49 women with a history of smoking, $38(77.5 \%)$ reported an increased desire to quit during pregnancy. Of the 24 former smokers, $12(50 \%)$ reported that they had stopped smoking because they were pregnant. It is of note that $38(77.5 \%)$ of the women with

Table 1 - Characteristics of the 61 pregnant women evaluated.

\begin{tabular}{lccc}
\hline \multicolumn{1}{c}{ Variable } & Smokers & Former smokers & Never-smokers \\
\hline $\mathrm{n}$ (\% of the sample as a whole) & $25(40.9)$ & $24(39.3)$ & $12(19.8)$ \\
Mean age (years), mean \pm SD & $26.4 \pm 7.4$ & $26.4 \pm 8.3$ & $25.1 \pm 7.2$ \\
Married, $\mathrm{n}(\%)$ & $16(64.0)$ & $13(54.2)$ & $7(58.3)$ \\
Level of education (years of schooling), $\mathrm{n}(\%)$ & & & \\
$\quad \mathrm{x} 9$ & $14(56.0)$ & $10(41.7)$ & $4(33.3)$ \\
$\quad 10-12$ & $8(32.0)$ & $9(37.5)$ & $7(58.3)$ \\
$\quad>12$ & $3(12.0)$ & $5(20.8)$ & $10(8.4)$ \\
Passive smoking, $\mathrm{n}(\%)$ & $18(72.0)$ & $11(45.8)^{*}$ & $4(33.3)$ \\
History of abortion, $\mathrm{n}(\%)$ & $5(20.0)$ & $7(29.2)$ & $0(0.0)$ \\
Abortion due to fetal malformation, $\mathrm{n}(\%)$ & $3(12.0)$ & $2(8.3)$ & \\
\hline
\end{tabular}

${ }^{*} p=0.049$ vs. smokers and never-smokers. 
a history of smoking did not know that smoking cessation treatments were available, and that $40(65 \%)$ of the women interviewed expressed a desire to have more knowledge about the adverse health consequences of smoking. Alcohol consumption during pregnancy was reported by a considerable proportion of the women with a history of smoking (42.9\%), and most (85.7\%) of those women reported an increase in cigarette consumption when drinking.

In our sample, the electronic media available to pregnant women included video players (in $36.1 \%$ ), radio (in $62.3 \%$ ), and television (in $85.2 \%$ ). Television was also the medium most

Table 2 - Alternative forms of tobacco consumption during pregnancy, by smoking status.

\begin{tabular}{lcc}
\hline \multicolumn{1}{c}{ Variable } & Smokers & $\begin{array}{c}\text { Former } \\
\text { smokers }\end{array}$ \\
\cline { 2 - 3 } & $(\mathrm{n}=25)$ & $(\mathrm{n}=24)$ \\
\hline Flavored cigarettes, $\mathrm{n}(\%)$ & $12(48.0)$ & $13(54.2)$ \\
Clove cigarettes, $\mathrm{n}(\%)$ & $7(28.0)$ & $6(25.0)$ \\
Narghile, $\mathrm{n}(\%)$ & $5(20.0)$ & $7(29.2)$ \\
Electronic cigarettes, $\mathrm{n}(\%)$ & $2(8.0)$ & $0(0.0)$ \\
\hline
\end{tabular}

preferred for relaxation/enjoyment (by 49.2\%). Internet use was still somewhat limited in this population, being cited by only $21(34.4 \%)$ of the 61 women interviewed.

\section{Discussion}

The main findings of the present study were that, among the pregnant women evaluated, there was a high prevalence of active and passive smoking during pregnancy; considerable usage of alternative forms of tobacco consumption during pregnancy; high levels of alcohol consumption during pregnancy; and limited knowledge of the adverse health consequences of smoking, including pregnancy outcomes for the fetus and newborn infant. On the basis of the preferences expressed by the interviewees, television appears to be the medium most well suited to delivering educational materials to this population (pregnant women).

We found a high (40.9\%) prevalence of active smoking among pregnant women, and $72 \%$ of the pregnant smokers also reported being exposed

Table 3 - Levels of anxiety and depression among pregnant women, according to the Hospital Anxiety and Depression Scale scores, by smoking status.

\begin{tabular}{ccccc}
\hline Variable & Total & Smokers & Former smokers & Never-smokers \\
\cline { 2 - 5 } & $(\mathrm{n}=61)$ & $(\mathrm{n}=25)$ & $(\mathrm{n}=24)$ & $(\mathrm{n}=12)$ \\
\hline $\begin{array}{c}\text { Anxiety, } \mathrm{n}(\%) \\
\text { Possible }^{\mathrm{a}}\end{array}$ & $11(18.0)$ & $5(20.0)$ & $5(20.8)$ & $1(8.3)$ \\
Probable $^{\mathrm{b}}$ & $13(21.3)$ & $7(28.0)$ & $2(8.3)$ & $4(33.3)$ \\
$\begin{array}{c}\text { Depression, } \mathrm{n}(\%) \\
\text { Possible }^{\mathrm{a}}\end{array}$ & $8(13.1)$ & $3(12.0)$ & $2(8.3)$ & $2(16.7)$ \\
Probable $^{\mathrm{b}}$ & $5(8.2)$ & $4(16.0)$ & $0(0.0)$ & $1(8.3)$ \\
\hline
\end{tabular}

${ }^{\mathrm{a}}$ Hospital Anxiety and Depression Scale score of 8-10. ${ }^{\mathrm{b}} \mathrm{Hospital}$ Anxiety and Depression Scale score of 11-21.

Table 4 - Knowledge of and beliefs about the health consequences of smoking for maternal, fetal, and neonatal outcomes, on the part of pregnant smokers and former smokers.

\begin{tabular}{lcc}
\hline \multicolumn{1}{c}{ Variable } & Smokers & Former smokers \\
\cline { 2 - 3 } & $(\mathrm{n}=25)$ & $(\mathrm{n}=24)$ \\
\hline Maternal health & & $7(29.2)$ \\
$\quad$ Lung disease, $\mathrm{n}(\%)$ & $2(24.0)$ & $6(25.0)$ \\
$\quad$ Abortion/placental damage, $\mathrm{n}(\%)$ & $1(8.0)$ & $1(4.2)$ \\
$\quad$ Cardiovascular disease, $\mathrm{n}(\%)$ & $1(4.0)$ & $0(0.0)$ \\
Cancer, n (\%) & $15(60.0)$ & $10(40.6)$ \\
No problems, $\mathrm{n}(\%)$ & & $5(20.8)$ \\
Fetal/neonatal health & $9(36.0)$ & $6(25.0)$ \\
Lung disease (\%) & $6(24.0)$ & $13(54.2)$ \\
Gestational problems, ${ }^{*} \mathrm{n}(\%)$ & $10(40.0)$ & \\
No harm to the fetus/neonate & &
\end{tabular}

*Prematurity, malformation, or low birth weight. 


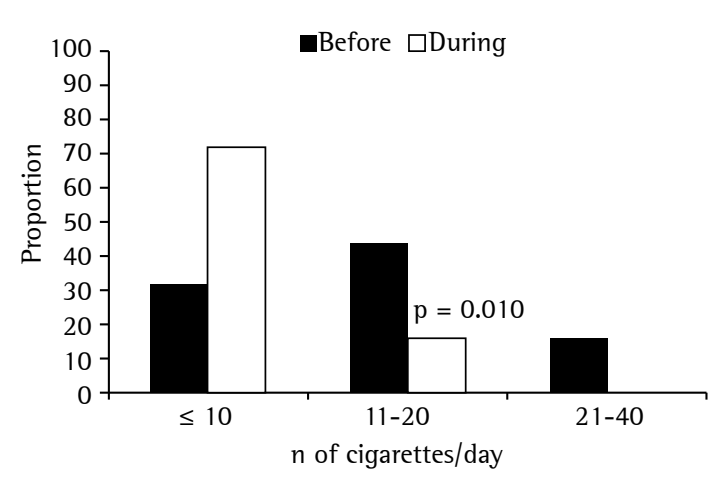

Figure 1 - Daily consumption of cigarettes before and during pregnancy among expectant mothers in the city of Botucatu, Brazil ( $n=49$ ).

to secondhand smoke during pregnancy. The prevalence of active smoking was higher than the 19.2-23.3\% reported in the national and international literature. ${ }^{(1)}$ It should be borne in mind that this study was not designed to determine the prevalence of smoking among pregnant women in general. In fact, some of the participants were recruited from a university hospital with a prenatal outpatient clinic primarily targeting women with high-risk pregnancies, which can be associated with other disorders that predispose to increased smoking. To our knowledge, there have been no previous studies evaluating the prevalence of smoking in this subgroup of pregnant women. However, this could explain, at least in part, the high prevalence of current smoking in our study sample and indicates the need to develop prevalence studies and offer individualized smoking cessation programs at such clinics. The prevalence of passive smoking in our sample (63.9\%) is comparable to the 39.2$56.7 \%$ reported in other studies of pregnant women. ${ }^{(8,12)}$

Our results show that a high proportion of pregnant former smokers lived with a neversmoker husband, which is consistent with the findings of previous studies showing a tendency for pregnant women to stop smoking if they have a husband who has never smoked. ${ }^{(13)}$ In addition, according to data in the literature and from the present study, pregnancy promotes smoking cessation, and that window of opportunity is not being taken advantage of, as evidenced by the fact that $77.5 \%$ of the smokers and former smokers interviewed in our study did not know that smoking cessation treatment was available. ${ }^{(14)}$ Furthermore, at least two studies have reported that mothers feel guilty about smoking during pregnancy. ${ }^{(14,15)}$ Therefore, a carefully presented appeal to consider smoking cessation treatment before or during pregnancy could be an effective strategy targeting this population of women.

We found that a high proportion of the pregnant women interviewed smoked flavored cigarettes or consumed tobacco in other alternative forms. The prevalence of those forms of tobacco consumption among pregnant women in Brazil remains unknown. Like traditional (cigarette) smoking, alternative forms of tobacco consumption have adverse health consequences. ${ }^{(16)}$ Therefore, smoking cessation interventions should include information about alternative forms of tobacco use, and that information needs to be widely disseminated.

Of the pregnant women interviewed in the present study, fewer than 30\% were aware of the effects that smoking has on respiratory health, and a similar proportion knew that smoking during pregnancy could lead to spontaneous abortion or damage the placenta. The consequences of maternal smoking for the fetus and newborn infant, such as prematurity, malformation, and low birth weight, were also known by only approximately $30 \%$ of the participants. Unfortunately, $40 \%$ of the smokers and $54.2 \%$ of the former smokers believed that smoking did not cause harm to the fetus or newborn infant. In addition, fewer than $6 \%$ of the women we interviewed were aware of the fact that smoking is associated with cardiovascular disease and cancer. These findings are consistent with those of studies showing that pregnant women possess only superficial knowledge of the health consequences of smoking during pregnancy. ${ }^{(12,15)}$

We found that the pregnant women evaluated in the present study presented with certain risk factors for smoking..$^{(12,13)}$ The majority had a low level of formal education, and alcohol consumption during pregnancy was common (reported by 42.9\%). Freire et al. ${ }^{(17)}$ also identified alcohol consumption during pregnancy in $31.3 \%$ of the pregnant smokers they evaluated. Similarly, Kroef et al. ${ }^{(18)}$ showed that, among pregnant women, smokers and former smokers consumed more alcohol than did never-smokers. In the present study, 39.3\% of the pregnant women evaluated had scores of the HADS that were suggestive of anxiety and 21.3\% had HADS scores suggestive of depression. Anxiety disorders are common during pregnancy, ${ }^{(19,20)}$ and depression 
has been associated with difficulty in quitting smoking among women, a situation than can be compounded by pregnancy. ${ }^{(19,21)}$ Park et al. ${ }^{(21)}$ and Solomon et al. ${ }^{(22)}$ both demonstrated that, in women who spontaneously stopped smoking during pregnancy, there was a positive association between depressive symptoms at the end of pregnancy and relapse to smoking in the postpartum period..$^{(21,22)}$

Among the pregnant women evaluated in the present study, television, the internet, and radio were the most widely used forms of electronic media, television being the form preferred by the largest proportion of the participants. Studies have shown that sending text messages (via mobile phone) advising pregnant women to quit smoking is an effective way to encourage smoking cessation during pregnancy, as is promoting interaction among pregnant smokers via online social networks. ${ }^{(23,24)}$ However, Bot et al. ${ }^{(25)}$ evaluated the differences in internet usage by pregnant women with different levels of education and found that those who had a low level of education were less interested in receiving e-mails about health issues than were those who had a higher level of education. In view of our finding that $65 \%$ of the pregnant smokers in the present study expressed a desire to increase their knowledge of the health consequences of smoking, we believe that educational interventions might be beneficial to these smokers.

In conclusion, the results of our study indicate that there is a high prevalence of active and passive smoking among pregnant women and that such women have limited knowledge about the health consequences of smoking, during pregnancy and otherwise. Pregnancy provides a window of opportunity for promoting smoking cessation and should be viewed as an excellent opportunity to provide more information about the health hazards of smoking and to offer smoking cessation treatment to pregnant women. Educational programs that include information about the consequences of all forms of tobacco use, employing new and effective formats tailored to this particular population, should be developed. Despite large-scale media campaigns, the level of knowledge among pregnant women regarding the long-term consequences of tobacco use remains low, and the use of alternative forms of tobacco is high among such women. However, pregnant women expressed interest in learning more about the subject, and television might be a useful tool for delivering information to this population in an attractive and continuous manner.

Potential limitations of the present study include the small sample size and the fact that it was conducted in only one city. In addition, the study sample comprised high-risk pregnant women. Therefore, the results cannot be extrapolated to pregnant women in general or to other regions of Brazil. However, because all of the women invited to participate in the study agreed to be included, there was no selection bias.

We believe that our study has added to the body of information supporting the development and implementation of new tools to improve the treatment of smoking during pregnancy. The use of material tailored to pregnant smokers and delivered in the form of videos shown or distributed to pregnant women during prenatal visits to outpatient clinics might promote smoking prevention and cessation among such women.

\section{References}

1. Floyd RL, Zahniser SC, Gunter EP, Kendrick JS. Smoking during pregnancy: prevalence, effects, and intervention strategies. Birth. 1991;18(1):48-53. http://dx.doi. org/10.1111/j.1523-536X.1991.tb00054.x

2. Del Ciampo LA, Ricco RG, Ferraz IS, Daneluzzi JC, Martinelli Jr CE. Prevalência de tabagismo e consumo de bebida alcoólica em mães de lactentes menores de seis meses de idade. Rev Paul Pediatr. 2009;27(4):361-5. http://dx.doi.org/10.1590/S0103-05822009000400003

3. Zhang L, González-Chica DA, Cesar JA, Mendoza-Sassi RA, Beskow B, Larentis N, et al. Maternal smoking during pregnancy and anthropometric measurements of newborns: a population-based study in southern of Brazil [Article in Portuguese]. Cad Saude Publica. 2011;27(9):1768-76. http://dx.doi.org/10.1590/S0102-311X2011000900010

4. Centers for Disease Control and Prevention (CDC). Healthcare provider screening for tobacco smoking and advice to quit - 17 countries, 2008-2011. MMWR Morb Mortal Wkly Rep. 2013;62(46):920-7.

5. Volchan E, David IA, Tavares G, Nascimento BM, Oliveira JM, Gleiser S, et al. Implicit motivational impact of pictorial health warning on cigarette packs. PLoS One. 2013;8(8):e72117. http://dx.doi.org/10.1371/journal. pone. 0072117

6. Levy D, Jiang M, Szklo A, de Almeida LM, Autran M, Bloch M. Smoking and adverse maternal and child health outcomes in Brazil. Nicotine Tob Res. 2013;15(11):1797804. http://dx.doi.org/10.1093/ntr/ntt073

7. Viegas CA. Noncigarette forms of tobacco use. J Bras Pneumol. 2008;34(12):1069-73. http://dx.doi.org/10.1590/ S1806-37132008001200013

8. Horta BL, Victora CG, Barros FC, dos Santos lda S, Menezes AM. Tobacco smoking among pregnant women in an urban area in southern Brazil, 1982-93 [Article in Portuguese]. Rev Saude Publica. 1997;31(3):247-53. 
9. Zigmond AS, Snaith RP. The hospital anxiety and depression scale. Acta Psychiatr Scand. 1983;67(6):361-70. http:// dx.doi.org/10.1111/j.1600-0447.1983.tb09716.x

10. Heatherton TF, Kozlowski LT, Frecker RC, Fagerström KO. The Fagerström Test for Nicotine Dependence: a revision of the Fagerström Tolerance Questionnaire. Br J Addict. 1991;86(9):1119-27. http://dx.doi. $\operatorname{org} / 10.1111 / \mathrm{j} .1360-0443.1991 . t b 01879 . x$

11. DiClemente CC, Prochaska JO. Self-change and therapy change of smoking behavior: a comparison of processes of change in cessation and maintenance. Addict Behav. 1982;7(2):133-42. http://dx.doi. org/10.1016/0306-4603(82)90038-7

12. Rozov T, Fiss E, Catherino P, Perestrelo Ml, Nomura M. Hábito de fumar das gestantes e parturientes de um hospital universitário e seus conhecimentos sobre os efeitos do fumo em fetos e lactentes. Arq Med ABC. 2004;29(1):28-36.

13. Rore C, Brace V, Danielian P, Williams D. Smoking cessation in pregnancy. Expert Opin Drug Saf. 2008;7(6):727-37. http://dx.doi.org/10.1517/14740330802196756

14. Fontanella BJ, Secco KN. Gestação e tabagismo: representações e experiências de pacientes de unidades de saúde da família. J Bras Psiquiatr. 2012;61(3):168-75. http://dx.doi.org/10.1590/S0047-20852012000300008

15. Possato M, Parada CM, Tonete VL. Representation of pregnant smokers on cigarette use: a study carried out at a hospital in the interior of the state of São Paulo [Article in Portuguese]. Rev Esc Enferm USP. 2007;41(3):434-40. http://dx.doi.org/10.1590/S0080-62342007000300013

16. Healton CG, Beck SE, Cartwright J, Vallone DM. Prohibiting menthol in tobacco products: a policy whose time has come. Addiction. 2010;105 Suppl 1:5-7. http://dx.doi. org/10.1111/j.1360-0443.2010.03205.x

17. Freire K, Padilha Pde C, Saunders C. Factors associated to alcohol and smoking use in pregnancy [Article in Portuguese]. Rev Bras Ginecol Obstet. 2009;31(7):335-41. http://dx.doi.org/10.1590/S0100-72032009000700003
18. Kroeff LR, Mengue SS, Schmidt Ml, Duncan BB, Favaretto AL, Nucci LB. Correlates of smoking in pregnant women in six Brazilian cities [Article in Portuguese]. Rev Saude Publica. 2004;38(2):261-7. http://dx.doi.org/10.1590/ S0034-89102004000200016

19. Lumley J, Chamberlain C, Dowswell T, Oliver S, Oakley L, Watson L. Interventions for promoting smoking cessation during pregnancy. Cochrane Database Syst Rev. 2009;(3):CD001055. http://dx.doi.org/10.1002/14651858. CD001055.pub3

20. Reichert J, Araújo AJ, Gonçalves CM, Godoy 1, Chatkin JM, Sales MP, et al. Smoking cessation guidelines--2008. J Bras Pneumol. 2008;34(10):845-80. http://dx.doi. org/10.1590/S1806-37132008001000014

21. Park ER, Chang Y, Quinn V, Regan S, Cohen L, Viguera A, et al. The association of depressive, anxiety, and stress symptoms and postpartum relapse to smoking: a longitudinal study. Nicotine Tob Res. 2009;11(6):70714. http://dx.doi.org/10.1093/ntr/ntp053

22. Solomon LJ, Higgins ST, Heil SH, Badger GJ, Thomas CS, Bernstein IM. Predictors of postpartum relapse to smoking. Drug Alcohol Depend. 2007;90(2-3):224-7. http://dx.doi.org/10.1016/j.drugalcdep.2007.03.012

23. Fujioka N, Kobayashi T, Turale S. Short-term behavioral changes in pregnant women after a quit-smoking program via e-learning: a descriptive study from Japan. Nurs Health Sci. 2012;14(3):304-11. http://dx.doi. org/10.1111/j.1442-2018.2012.00702.x

24. Lowe JB, Barnes M, Teo C, Sutherns S. Investigating the use of social media to help women from going back to smoking post-partum. Aust N Z J Public Health. 2012;36(1):30-2. http://dx.doi.org/10.1111/j.1753-6405.2012.00826.x

25. Bot M, Milder IE, Bemelmans WJ. Nationwide implementation of Hello World: a Dutch email-based health promotion program for pregnant women. J Med Internet Res. 2009;11(3):e24. http://dx.doi.org/10.2196/ jmir. 1183

\section{About the authors}

\section{André Luís Bertani}

Doctoral Student. Pulmonology Division, Department of Clinical Medicine, Botucatu School of Medicine, São Paulo State University, Botucatu, Brazil.

\section{Thais Garcia}

Physiotherapist. Botucatu Hospital das Clínicas, Botucatu School of Medicine, São Paulo State University, Botucatu, Brazil.

\section{Suzana Erico Tanni}

Professor. Pulmonology Division, Department of Internal Medicine, Botucatu School of Medicine, São Paulo State University, Botucatu, Brazil.

\section{Irma Godoy}

Full Professor. Pulmonology Division, Department of Internal Medicine, Botucatu School of Medicine, São Paulo State University, Botucatu, Brazil. 